\title{
Huszár Zoltán \\ PILLANTÁS A DUNAI GŐZHAJÓZÁS KEZDETEIBE ÉS A DGT CSÚCSIDŐSZAKÁBA
}

\begin{abstract}
Absztrakt
A dolgozat a gőzhajózás amerikai előzményeitől a dunai gőzhajózás 19. század 20-as éveinek Bernhard Antal (Anton Bernhard) nevéhez köthető eredményeinek bemutatásával igyekszik rávilágítani az ipari forradalom magyarországi kezdeteinek időszakára, illetve arra a nem könnyű helyzetre, ami az akkori feltalálók és vállalkozók életét jellemezte.

Mindent összevetve Bernhard tevékenysége úttörő jellegű és egyben példaértékű is; ugyanis azt bizonyította, hogy makacs kitartással, feltalálói innovációval a Dunán is lehetséges (lenne) korszerű folyami közlekedést megvalósítani. Ehhez azonban elengedhetetlennek tűnt a megfelelő tőkeerő és a politikai támogatás. E két tényező egyesítésére legjobb példa az Első cs. kir. szab. Dunagőzhajózási Társaság (DGT) / (Erste k. k. priv. DonauDampfschifffahrts-Gesellschaft /DDSG/) története, amely 1829. évi bécsi alapítása után háromnegyed évszázaddal nemcsak a Duna-medence legnagyobb hajózási vállalata, hanem a világ legnagyobb belvízi hajózási társasága is lett, sok vonatkozásban meghatározva a Duna-medence, különösen Dél-Dunántúl történetét. E fejlődés szimbólumának is tekinthető a DGT luxusgőzöse, a Sophie.
\end{abstract}

Kulcsszavak: gőzhajózás a Dunán; Anton Bernard; DGT; Sophie

A jelen dolgozatommal sok szeretettel köszöntöm Minorics Tünde és Bokor Béla kollégáimat, barátaimat, akik a Duna-mentéről indultak az életbe és akik 2021-ben „kerek” születésnapot ünnepelnek. Több évtizedes ismeretség, szakmai együttmüködés után kívánok nekik további jó egészséget, sikereket egyetemi oktató és kutató munkájukhoz, újabb eredményeket a kultúraközvetítés területén és persze boldog hétköznapokat.

\section{Bevezetés}

A 18-19. század ipari forradalmában az erőforrások területén a gőzgépeknek, a közlekedésben a gőzhajózásnak és a vasútnak meghatározó szerep jutott. Mindezek számára az energiaforrás, a fütőanyag a szén volt.

A gőzhajózásra vonatkozó első hitelesnek tekinthető adatok Észak-Amerikából származnak és John Fitch hajóira vonatkoznak, amelyek 1787-ben Philadelphia és Trenton között közlekedtek (Pallas VII. k., 1897; Tóth, 1963.; Jankó, 1967). Fitch vállalkozása azonban tönkrement, és a világ a gőzhajó feltalálójának Robert Fultont tekinti, aki 1807. október 7-én indult „Clermont” nevű lapátkerekes hajójával - amelyet a Boulton, Watt \& Co. 
(Grössing, Funk, Sauer \& Binder) által készített 20 lóerős gőzgép hajtott - és a Hudson folyón a New York és Albany közötti 240 km-es távolságot 32 óra alatt tette meg (Pallas VII. k., 1897; Tóth, 1963).

\section{A gőzhajózás kezdetei Magyarországon}

Magyarországon a 18. század végén Bécs és Pest között, a korabeli közlekedési viszonyokhoz képest, élénk volt a dunai forgalom, ami a gyakorlatban azt jelentette, hogy hetente rendszeresen indultak iparcikkekkel megrakott hajók Magyarországra. A nyugati áruk elosztóhelye Pest volt. Ennek mintegy ellentételezéseként jelentős gabonaszállítások történtek az ország délkeleti részéből északnyugati irányba. A magyar Dunán évenként mintegy 3 millió mérő ${ }^{1}$ gabonát szállítottak Győr felé, a Száván pedig kb. egy millió mérőt. (Pallas XII. k., 1896) A hajók a folyókon lefelé úsztak, azaz ereszkedtek, felfelé pedig a fáradtságos, partról történő vontatással mozgatták a hajókat (Jankó, 1967). Éppen ezért II. József olyan uralkodói rendeletet bocsátott ki, amely többek között a vontató utak rendben tartásáról is szólt. A vontatás nagyrészt állati erővel - lovakkal, néha ökrökkel - történt, de gyakran emberi erőt, büntetésként rabokat is alkalmaztak e kegyetlen munkára. A császári büntetőtörvénykönyv például az egyik legsúlyosabb büntetésként írta elő a hajóvontatást. (Petrović, 1982) E szállítás azonban nagyon körülményes, nehezen kiszámítható, lassú és nem utolsó sorban időigényes, költséges tevékenység volt. Pesttől Bécsig hajón az utazás általában 20, de néha 25 napig is eltartott (Gonda, 1894).

A magyarországi gőzhajózás meghonosításával már a 18. század végén többen próbálkoztak, de eredményt kevesen értek el. Megemlítendő gróf Batthyány Tivadar, aki „1793ban 20 lóerőre szóló szabadalmat nyert, egy 'Stromaufwärts Fahrzeug'-ra, ami azután a 'Neuen Kgl. Priviligierten Schiffbau und Schiffahrts Compagnie' alapítására vezetett." (Tóth, 1963, p. 15). A kiváltságlevél nyomán készített, titokzatos módon mozgatott hajóját 1797-ben Bécsben be is mutatta, de a korabeli források a gőzhajtást egyértelműen nem támasztották alá és a későbbi szakirodalom is ezt erősíti meg (Dezsényi \& Hernády, 1967).

A gőzhajózás, amely az Egyesült Államokban, Angliában és ezt követően Nyugat-Európa folyóin is gyorsan elterjedt, a Dunán az 1810-es években mutatkozott be. Az Udvari Kamara a „Wiener Zeitung” 1813. évi július 27-i számában közleményt jelentetett meg, amelyben szabadalmat helyez kilátásba annak, aki „áruval terhelt hajóknak vontató állatok felhasználása nélkül, vízfolyás ellen való vontatásának találmányával jelentkezik" (Jankó, 1967, p. 6). A közleményt a magyar Helytartótanács 1813. szeptember 6-án Magyarországon is közzétette. Vélhetően az érdeklődők alacsony száma vagy hiánya miatt ezt követően a „Wiener Zeitung” 1817. évi november 17-i számában újabb 12 pontból álló felhívás látott napvilágot, amely részletesen körülírta a szabadalom elnyerésének feltételeit. A Helytartótanács 1817. december 17-én megküldte az anyagot a megyéknek kihirdetés céljából. „Minekutána az 1813 júliusnak 7-ik napján Őfelségének kegyelmes parancsolatja szerint közrebocsájtott tudósítás, hogy annak, aki oly leleményt, melynek segedelmével a terhes hajókat vontató barmok nélkül a víznek folyása ellen felfelé lehessen vinni, bejelent és haszonra való fordítását próbatétel által megmutatja, e leleményre egy

11 (pozsonyi) mérő = 62,39 l; Bán (szerk.) II. k. p. 35 . 
hozzászabott és kizárólagos privilégium fog adatni...” (Jankó, 1967, p. 6). Mindezt az uralkodó azért tartotta fontosnak, mert „... a más országokban már foganatosan szokásba vett gőzhajók az ausztriai Monarchiában még gyakorlatba nem hozattak..." (Jankó, 1967, p. 6). A közlemény részletesen meghatározta a gőzhajózási privilégium közlekedési, műszaki, jogi feltételrendszerét, amely egyben 15 esztendőre szóló kiváltságot is jelent a sikeres pályázó számára. A privilégiumot elnyert vállalkozó jogosítványai „....a gőzhajózásra, a kizáró privilégiumnak az ausztriai Monarchia nem egész környékére, hanem csak a különös főfolyók és ezeknek mellékvizei szerint, vagy a tengeri hajózásnak határozott arányai szerint a Monarchiának egyik pontjától a másikig adatnak." (Jankó, 1967, p. 6)

A felhívás közzététele után a dunai gőzhajózás egy amerikai mérnök érdeklődését is felkeltette. Israel I. Richartson Baltimore-ban 1818. augusztus 25-én kelt, Metternich herceghez szóló levelében az iránt érdeklődött, hogy a herceg szabadalmaztatná-e „Tökéletesített Rotációs Rendszerű Gőzgépét” (engine-jét), és kinevezné-e őt, mármint Richartsont az Osztrák Folyami Hajózás főfelügyelőjévé. Bár az amerikai szakember ajánlatát nem fogadták el, megállapításai érdekes jellemzést adtak a dunai folyami hajózásról. „Ausztriában nagyon erősen megpróbálják bevezetni a gőzhajózást, amelyhez a kormány minden lehetséges bátorítást garantál, bár abból, amit az erőfeszítéseikből láttam, összevetve ennek az országnak a gőzhajóival, úgy tűnik számomra, hogy rengeteg pénzt és időt fognak még a kísérletezésre szánni, mint ahogy az a nagy vállalkozásoknál mindig lenni szokott, mire elérik azt a tökéletességet, amely a mi országunkban (mármint az Egyesült Államokban H. Z.) jellemzőnek számít. ... Ha lennének szívesek példaként venni a Dunát, amely Ulmtól a Fekete-tengerig hajózható, ami 2.000 angol mérföldes szakaszt jelent, micsoda előnyös lenne bevezetni azon tartományok terményeinek gyors és olcsó szállítását, amelyeket Európa első folyója öntöz. Milyen kereskedelmi és katonai előnyökkel járna Ausztria számára, ha bevezetnék a gőzhajót, amely 3 1/2 vagy 4 nap alatt megtenné Semlintől (Zimonytól H. Z.) Bécsig az utat, majd Bécstől Ulmig 2 1⁄2 vagy 3 nap alatt, ahogy azt az Egyesült Államokban a gőzhajók teszik, ami óránként 3 angol mérföldet jelent a Duna folyásával szemben" (Hajnal, 1920, pp. 122-123). Források nem ismerek arra vonatkozóan, hogy reagált-e a bécsi kormányzat az amerikai szakember megállapításaira, és ha igen, miként.

A felhívás hatására Bernhard Antal (Anton Bernhard) pécsi lakos, az eszéki hídvám bérlője a Dráva melletti sellyei uradalomban megkezdte gőzhajója építését. Az épülő hajóról Berks M. Péter pécsi bányaigazgató a Vereinigte Ofner-Pester Zeitung 1817. január 23-i számában tudósított (Jankó, 1967). A „Tudományos Gyűjtemények” 1817. évi januárjában megjelent I. kötetében is beszámoltak a készülő gőzhajóról. „Egy ily gőzhajónak felállítására hazánkban is Pécsett egy társaság állott össze Bernhard Antal neve alatt (Bernhard und Comp.) ... Bécs városát fogja Magyarországgal a Duna vizén először egyesíteni. ... Az evégre szükséges gőz a vasasi kőszénből fejtetik ki." (Jankó, 1967, pp. 8-9). Az 1817. március 21-én vízrebocsátott hajó május 2-án mutatkozott be Bécsben, egyértelmű sikert aratva. Az uralkodó feleségéről elnevezett „Carolina” gőzös főbb adatai a következők voltak. Jankó Béla teljes terjedelmében közli a hajó 1818. január 3-i hatósági műszaki vizsgálatának anyagát, amelyből az alábbiakat emeltem ki (Jankó, 1967, pp. 8-9): 


$\begin{array}{ll}\text { hosszúság: } & 42 \text { bécsi láb }(13,27 \mathrm{~m}) \\ \text { szélesség: } & 10 \text { bécsi láb }(3,16 \mathrm{~m}) \\ \text { oldalmagasság: } & 3 \text { bécsi láb }(1,1 \mathrm{~m}) \\ \text { vízkiszorítás: } & 826 \text { bécsi mázsa }(426 \mathrm{q}) \text { (1 bécsi mázsa = } 56 \mathrm{~kg}) \\ \text { gépereje: } & 24 \mathrm{LE} \\ \text { géptípus: } & \text { egyhengeres dugattyús, álló gőzgép }\end{array}$

A ráhelyezett Stampel-gőzgép egyes részeinek súlya bécsi mázsában:

kazán

72 bécsi mázsa (40,30 q)

$6 \mathrm{db}$ réz gőzcső

4 bécsi mázsa (224 kg)

vízkészlete az egész gőzfejlesztő szerkezetnek 30 bécsi mázsa (16,8 q)

kerekek

30 bécsi mázsa $(16,8$ q)

lendítőkerekek

14 bécsi mázsa $(7,8 q)$

irányító görbecsapok

73 bécsi mázsa $(48,8$ q)

kazán falazása

150 bécsi mázsa ( $84 q)$

üres hajó

180 bécsi mázsa $(100,8$ q)

összesen:

516 bécsi mázsa (289 q)

1. kép: A Carolina gőzhajó

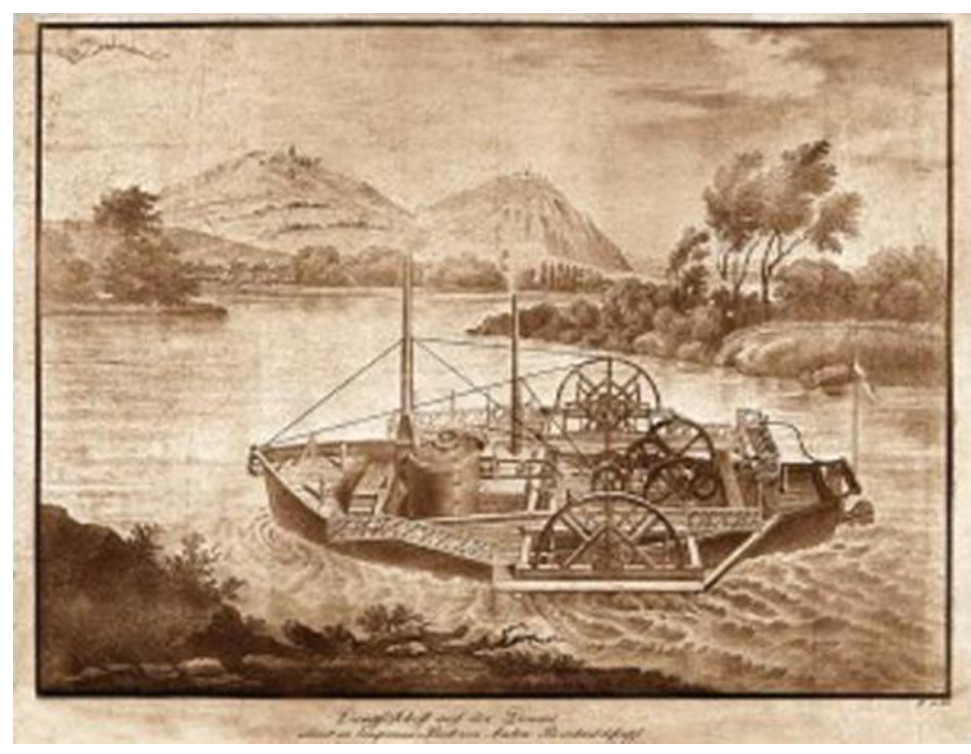

Forrás: Cultura \& MTI, 2013. szeptember 7.

„Ha az összes súlyt levonjuk, úgy 273 bécsi mázsa (153 q) marad fenn, amelyet a gép saját magán, a hajóban lévő szénen, a csőrendszer felesleges falazatán kívül, mint ballasztot vagy rakományt haladás közben magával vihet. A gőzhajó egy mögéje akasztott teherhajóval, amelyben 350 bécsi mázsa (156 q) rakomány volt, hegymenetben percenként 30 öl (56,8 m) átlagos sebességgel haladt, és lefelé 150 ölet (284 m) tett meg. Az utána akasztott hajóval mind fel-, mind lefelé megállás nélkül fordult meg, úgyhogy a gőzhajózás nehéz feladata a Dunán megoldottnak tekinthető, amihez Bernhard Antal úr mind a gőzfejlesztésnél, mind a lapátkerekek mechanizmusánál bevezetett újításával és találmányaival, valamint egy különleges készülékével a hajó használati módjához jelentősen hozzájárult." 
(Jankó, 1967, pp. 10-12). Bernhard még több próbaúttal bizonyította hajója alkalmasságát a privilégium megszerzésére. Az osztrák hatóságok azonban csak további próbautak és nem kis bürokratikus nehézségeket támasztva adták meg Bernhard számára 1819. január 11-én a gőzhajózási privilégiumot. (Jankó, 1967). Ezzel párhuzamosan egy Chevalier de St. Leon nevű vállalkozó is kapott dunai hajózási engedélyt, azonban osztrák szerzők mindkét hajózási privilégium kiadását 1818. december 31-ére teszik (Grössing, Funk, Sauer \& Binder,1979). Chevalier de St. Leon azonban - hamarosan világossá vált - nem tudott megfelelni az engedély kritériumainak. 1818. évi vállalkozása részben szervezési, részben személyi vonatkozásban közvetlen kapcsolatba hozható egy későbbi, 1823-ban múködési engedélyt kapott hajózási társasággal. Ezt a feltételezést látszik igazolni az udvari kamara azon intézkedése, miszerint röviddel azután, hogy a DGT-t megalapító két angol, John Andrews és Joseph Pritchard számára a dunai gőzhajózás privilégiumát kiadták (Grüssing, Funk, Sauer \& Binder, 1979), megszűntnek nyilvánították St. Leon engedélyét. Hivatalos levélváltás útján az udvari kamara tájékozódott az 1823-as társaság akkoriban Varsóban tevékenykedő képviselőinél. Bécsben a vállalkozás korábbi vezetője elismerte, hogy már hosszú ideje nincs kapcsolata a társasággal. A részvénytársaság egyik alapító tagja, Jacob von Löwentahl, aki alapító tagja lett az 1829-es DGT-nek is, írásban közölte, hogy az általuk használt gőzhajót, az „I. Ferenc”-et (ami nem azonos a DGT 1830ban vízre bocsátott, ugyancsak I. Ferencről elnevezett gőzösével) „eladták, és a privilégium folytatása ügyében semmit sem kezdeményeztek” (Grössing, Funk, Sauer \& Binder, 1979, p. 16). A Bécsi Kereskedelmi és Váltóügyi Bíróság (Wiener Merkantil- und Wechselgericht ) ezért a céget megszűntnek nyilvánította, az udvari kamara pedig 1829. október 26-án a társaság privilégiumát bevonta (Grössing, Funk, Sauer \& Binder, 1979).

Bernhard hajójával az engedély megszerzése, 1819. január 11-e után dunai folyami szállításokat végzett, illetve 1820-ban Pest és Óbuda között folyami átkelő feladatokat is ellátott. A töretlen akaraterejű Bernhard 1821. július 15-én hajózási vállalatot alapított (Jankó, 1967) amely azonban hosszú távon, tőkehiány miatt nem lehetett sikeres. 1821. november 25-én I. Ferenctől újabb gőzhajózásra szóló kiváltságlevelet nyert (Tóth, 1963), amelyet alapvetően egy újfajta kerék gőzzel történő meghajtása miatt kapott.

Mindent összevetve Bernhard tevékenysége úttörő jellegű és egyben példaértékű is; ugyanis azt bizonyította, hogy a Duna-medencében is lehetséges (lenne) korszerű folyami közlekedést megvalósítani. Ehhez azonban elengedhetetlennek tűnt a megfelelő tőkeerő és a politikai támogatás. E két tényező egyesítésére jó példa az Első cs. kir. szab. Dunagőzhajózási Társaság története, amely Bernhard után háromnegyed évszázaddal nemcsak a Duna-medence legnagyobb hajózási vállalata, hanem a világ legnagyobb belvízi hajózási társasága is lett. 


\section{A DGT és a „Sopie”}

Az 1829-ben Bécsben Első cs. kir. szab. Dunagőzhajózási Társaság /DGT/ (Erste k. k. priv. Donau-Dampfschiffahrts-Gesellschaft /DDSG) (a továbbiakban DGT, vagy Társaság) a 19. század második felétől a 20. század közepéig az egykori Osztrák-Magyar Monarchia, ill. a két világháború közötti Magyarország, valamint Ausztria egyik legjelentősebb ipari nagyvállalatának, egyben a dél-dunántúli térség gazdasági „zászlóshajójának” is számított (Grössing, Funk, Sauer \& Binder, 1979). Mindez pedig alapvetően annak köszönhető, hogy az értékes mecseki feketekőszenet a DGT által indított nagyipari bányászat korszerű formában kapcsolta be az említett időszak gazdasági vérkeringésébe, s ezzel megalapozta a több, mint két évszázados múltra visszatekintő pécsi szénbányászat európai rangját és ismertségét.

A DGT a Kárpát-medence, ezen belül különösen a Duna hajózását igyekezett - vertikálisan és horizontálisan egyaránt - átfogni. A 19-20. század fordulóján, ereje teljében több mint száz hajózási állomása volt a Duna-medencében. Ez a magyarázata annak is, hogy szénbányákat vásárolt a Mecsekben, hajóépítő és javító üzemeket működtetett - Korneuburgban, Galatzban, a legjelentősebbet Óbudán - valamint a szén szállítását is a saját fennhatósága alatt álló vasút, a Mohács-Pécsi Vasút megépítésével (1854-1857) kívánta megoldani. A jó fútőértékű mecseki feketeszén, amelynek bányái viszonylag közel estek a Dunához, a mohácsi kikötőhöz, arra késztette a vállalatot, hogy szilárdan megvesse a lábát a pécsi szénmedencében (Huszár, 1998).

1852 és 1923 között az összes Pécs környéki bánya vétel vagy bérlet útján a DGT fennhatósága alá került. Ezzel a mecseki kőszénbányászatban elkezdődött egy tőkeerős, a termelés műszaki feltételeit a kor színvonalához igazító, kiterjedt gazdasági, kereskedelmi és nem utolsósorban politikai kapcsolatokkal rendelkező nagyvállalat működése. A DGT jelentős gazdasági ereje, a Monarchia, majd az I. világháború után az osztrák és a magyar politikai élet legfelső köreihez fűződő kapcsolatai komoly befolyást gyakoroltak közel egy évszázadon át Pécs és Délkelet-Dunántúl életére (Huszár, 1995).

A téma osztrák szakértői formálisan az 1894. évet tekintik a DGT „csúcs” évének. Természetesen, ha egy tágabb periódust nézünk, akkor a DGT vállalati életében a 19-20. század fordulója jelentette a „csúcsidőszakot”, amikor a Társaság a világ legnagyobb belvízi hajózási vállalatának számított (Grössing, Funk, Sauer \& Binder, 1979).

Annak ellenére, hogy a jelen dolgozat elsősorban nem DGT-témájú, fontosnak tartom, hogy a DGT hajózási szempontból legjelentősebb időszakának legnagyobb személyszállító gőzösét bemutassam. E rövid ismertetés Gonda Béla (1899) műve alapján bepillantást enged a korabeli folyami közlekedés legelőkelőbbek számára biztosított viszonyaiba. Az első világháború előtt szolgálatba állított legnagyobb DGT hajó a „Sophie” volt, amelyet külön társaságok vagy fejedelmi személyek szállítására is használtak. Hossza 69,19 m, szélessége 7,92 m (a kerékszekrényeknél 10,15 m), magassága 2,74 m. Az első osztály fedélzetén volt az első osztályú étterem, közvetlenül mellette egy kisebb terem, nemdohányzó utasok részére. E kettő közötti válaszfal úgy volt megszerkesztve, hogy szükség esetén könnyen leszerelhető legyen, így a két termet egy helyiséggé lehetett alakítani. A gőzös fedélzetén volt még ezen kívül I. osztályú dohányzóterem, II. osztályú terem és a III. osztályú utasoknak fenntartott fedélzet, és természetesen meg kell említeni a hajóstisztek 
fülkéit, a konyhát, az éléskamrát, a pincérek lakrészeit és az illemhelyeket is. Ezen kívül volt a hajón még négy elegáns, kényelmesen berendezett külön utasfülke olyan utasok részére, akik az utazóközönség többi tagjától elkülönítve akartak étkezni, aludni és tartózkodni. Az étkezőterem falait selyemszövettel vonták be és tükrökkel díszítették. A gőzös összes helyiségében este és éjszaka villanyvilágítás működött. A fedélzet alatt voltak a rugós vaságyakkal, mosdókkal és általában minden kényelemmel felszerelt I. osztályú hálótermek, külön a férfiak és külön a hölgyek számára. A II. osztályú helyeken nem volt külön hálószoba, a II. osztályú terem padjait bőrrel átvont matracokkal látták el, amelyeket nappal ülésre, éjszaka alvásra használtak. A fedélzeti felépítmények fölött volt az ún. „sétafedélzet", amely az utazóközönség kényelmére padokkal, tábori székekkel volt berendezve, így kedvező időben az utasok kellemes és kedvelt tartózkodási helye volt. Itt napellenző ponyvák védtek a napsugarak ellen. A gőzösön természetesen mentőcsónakok és egyéb mentőeszközök is voltak. A „Sophie” rendes körülmények között anélkül, hogy zsúfolt lett volna, 1.050 személyt tudott kényelmesen befogadni. A gőzös mélyjárata, azaz legnagyobb merülése 25 tonna szénnel berakodva 1,16 m volt. A hajó - Goda szerint - 1858ban épült a DGT Óbudai Hajógyárában² 563 LE teljesítményű gőzgépét az Escher és Wyss zürichi cég építette. A gőzt két kerek, kettős kazán szolgáltatta, amelyek túlhevítővel is el voltak látva. A hajót két Morgan típusú kerék hajtotta. Egy-egy keréken 15 lapát volt (Gonda, 1899, pp. 125-126).

\section{2. kép: Sophie DGT /DDSG gőzös}

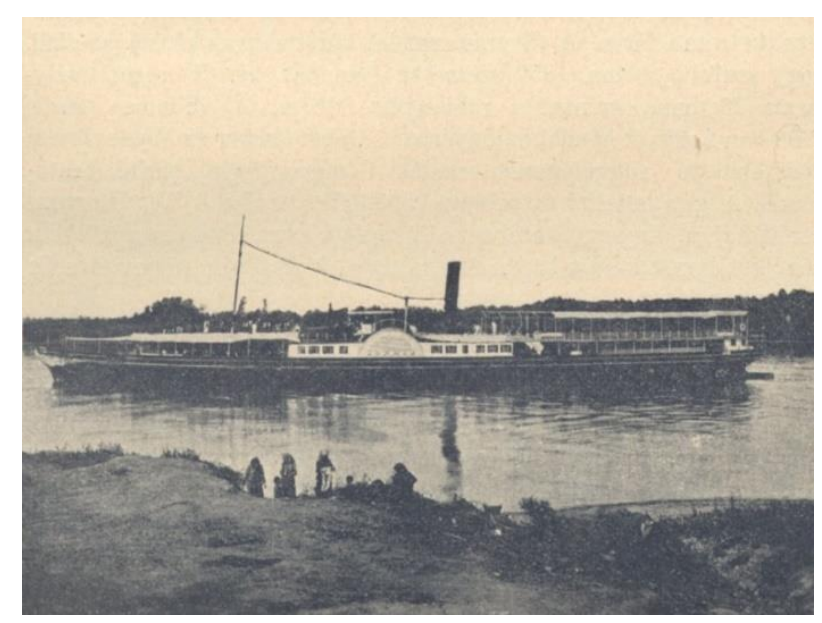

Forrás: OSZK MEK, 2012. április 12.

A „Sophie” ugyan a korabeli csúcstechnikát képviselte, de ha a többi DGT hajót is hasonlóan megvizsgálnánk, legtöbbjük nem sokkal maradna el tőle, legfeljebb kényelmi felszereltségük volt alacsonyabb szintű.

Tekintettel arra, hogy a DGT vagyontárgyainak nagy része Magyarországon volt, a Társaság igyekezett a mindenkori magyar kormánnyal jó viszonyt kialakítani, illetve fenntartani. Ennek külsőségekben is megnyilvánuló formája volt, hogy hajóit a magyar határok között 1908-ig magyar zászló alatt közlekedtette, sőt a budapesti helyi közlekedésű hajói,

\footnotetext{
2 Mayer és Winkler (1989) 1845-re teszi a „Sophie” építését és 680 LE-re a teljesítményét.
} 
amelyek üzemeltetésére a DGT a Budapest fővárosi közmunka tanácstól évi 200.000 korona támogatást kapott, 1916. október 31-ig használták a magyar nemzeti lobogót (Jankó, 1968). Érdemes megjegyezni, hogy a DGT hajók egyébként - Magyarországon kívül - soha sem a fekete-sárga, hanem a cs. kir. haditengerészetével azonos, piros-fehér-piros lobogót használták, amely a Társulat hivatalos színeinek számított (Dezsényi \& Hernády, 1967). Nem véletlen, hogy a „Rot-Weis-Rot auf blauen Wellen”/„Piros-fehér-piros a kék hullámokon" jelmondat adta a DGT 150 éves jubileumi kötetének a címét 1979-ben.

Reményeim szerint a dunai gőzhajózás kezdeteiről és legfejlettebb időszakáról szóló vázlatos történeti áttekintésem kedvet csinál az olvasónak ahhoz, hogy dunai hajózás további irodalmában is elmerüljön.

\section{Irodalomjegyzék}

Bán, P. (1989). Magyar Történelmi Fogalomgyűjtemény. Gondolat Kiadó.

Cultura \& MTI (2013. szeptember 7.). Carolina, az első dunai gőzhajó. Cultura. https://cultura.hu/aktualis/carolina-az-elso-dunai-gozhajo/. (Letöltés dátuma: 2021.06.15.)

Dezsényi, M. \& Hernády, F. (1967). A magyar hajózás története. Műszaki Könyvkiadó.

Gonda, B. (1899). A magyar hajózás. Műszaki, Irodalmi és Nyomdai Vállalat.

Grössing, H., Funk, E. U., Sauer, M., \& Binder, J. (1979). Rot-Weis-Rot auf blauen Wellen. 150 Jahre DDSG. Erste Donau-Dampfschiffahrts-Gesellschaft.

Hajnal, H. (1920). The Danube. Its Historical, Political, and Economic Importance. Martinus Nijhoff.

Huszár, Z. (1995). Az Első cs. kir. szab. Dunagőzhajózási Társaság szerepe a pécsi bányászatban és városfejlődésben a dualizmus időszakában. In V. Fodor, Zs. (szerk.), Vállalkozó polgárok a Dunántúlon a dualizmus korában (pp. 149-159). Laczkó Dezső Múzeum.

Huszár, Z. (1998). Pécs és a Dunagőzhajózási Társaság. Pécsi Szemle (1) ősz-tél, 69-84.

Jankó, B. (1967). A gőzhajózás kezdete a Dunán, „Carolina”, az első gőzhajó. A Közlekedési Múzeum Füzetei 2.

Jankó, B. (1968). A magyar dunai gőzhajózás története 1817-1947. Hajózástudományi Együttműködési Bizottság. Műszaki Történeti Sorozat 9. Gépipari Tudományos Egyesület.

Mayer, H. F., \& Winkler, D. (1989). Auf Donauwellen durch Österreich-Ungarn. Verlag der Österreichischen Staatsdrückerei.

OSZK MEK (2012. április 12.). A Sophie személyszállító gőzös. Fénykép. DKA-033732. https://dka.oszk.hu/html/kepoldal/index.phtml?id=033732\#. (Letöltés dátuma: 2021.06.15.)

Pallas Nagy Lexikona V. k. (1893). Pallas Irodalmi és Nyomdai Részvénytársaság.

Pallas Nagy Lexikona VII. k. (1897). Pallas Irodalmi és Nyomdai Részvénytársaság.

Pallas Nagy Lexikona XII. k. (1896). Pallas Irodalmi és Nyomdai Részvénytársaság.

Petrović, N. (1982). Hajózás és gazdálkodás a Közép-Duna-medencében a merkantilizmus korában. A DunaTisza csatorna építése és fáradozások a Közép-Duna-medence és az Adriai-tenger összekötésére a XVIII. század végén. Vajdasági Tudományos és Művészeti Akadémia Történelmi Intézet.

Tóth, L. (1963). 145 éves a magyar gőzhajózás (Dokumentációs tanulmány). Hajózástudományi Együttműködési Bizottság. Műszaki Történeti Sorozat 3. Gépipari Tudományos Egyesület. 